\title{
Реорганизация крестьянского
} (фермерского) хозяйства — юридического лица

Аннотация. В результате реформы гражданского законодательства значительно изменилось правовое положение крестьянского (фермерского) хозяйства. После долгого перерыва законодатель вновь признал возможным создание крестьянского (фермерского) хозяйства как юридического лица (наряду с крестьянскими (фермерскими) хозяйствами, не имеющими статуса юридического лица). Законодатель определил крестьянское (фермерское) хозяйство, являющееся юридическим лицом, как коммерческую корпоративную организацию, занимающую промежуточное положение между хозяйственными товариществами и хозяйственными обществами. Столь радикальная законодательная новелла не сопровождалась, к сожалению, установлением детального регулирования едва ли не всех важнейших вопросов создания, деятельности и прекращения нового вида юридического лица. В полной мере этот вывод распространяется и на основания, порядок, условия и последствия реорганизации этого вида юридического лица. Гражданский кодекс РФ (ст. 86.1) предполагает, что особенности правового положения крестьянского (фермерского) хозяйства, созданного в качестве юридического лица, должны определяться законом. Однако такого закона до сих пор нет. Федеральный закон от 11 июня 2003 г. № 74-Ф3 «О крестьянском (фермерском) хозяйстве» регулирует только особенности правового положения соответствующих хозяйств, не имеющих статуса юридического лица. На практике такое регулирование может создать немало сложностей при попытках реорганизовать крестьянское (фермерское) хозяйство - юридическое лицо.

Ключевые слова: юридическое лицо; коммерческая организация; корпорация; крестьянское (фермерское) хозяйство; реорганизация; преобразование; слияние; присоединение; разделение; выделение.

Для цитирования: Габов А. В. Реорганизация крестьянского (фермерского) хозяйства - юридического лица // Актуальные проблемы российского права. - 2020. - Т. 15. - № 5. - С. 79-95. - DOI: 10.17803/19941471.2020.114.5.079-095.

\section{Reorganization of a Peasant (Farm) Entity Functioning as a Legal Entity}

\author{
Andrey V. Gabov, Corresponding Member of the Russian Academy of Sciences, Doctor of Law, \\ Merited Lawyer of the Russian Federation, Chief Researcher, Institute of the State and Law, Russian \\ Academy of Sciences \\ ul. Znamenka, d. 10, Moscow, Russia, 119019 \\ gabov@igpran.ru
}

\begin{abstract}
As a result of the reform of civil legislation, the legal status of the peasant (farm) economy has significantly changed. After a long break, the law-maker has recognized the possibility of establishing a peasant (farm) entity as a legal entity (along with peasant (farm) entities without the status of a legal entity). The law-maker defined a

(C) Габов А. В., 2020

* Габов Андрей Владимирович, член-корреспондент Российской академии наук, доктор юридических наук, заслуженный юрист РФ, главный научный сотрудник Института государства и права Российской академии наук ул. Знаменка, д. 10, г. Москва, Россия, 119019

gabov@igpran.ru
\end{abstract}


peasant (farm) entity, which is a legal entity, as a commercial corporate organization that occupies an intermediate position between economic companies and economic societies. Such a radical legislative amendment was not accompanied, unfortunately, with the establishment of a detailed regulation of almost all the most important issues of creation, operation and termination of a new kind of the legal entity. This conclusion applies to the grounds, order, conditions and consequences of reorganization of this type of the legal entity. The Civil Code of the Russian Federation (art. 86.1) assumes that the features of the legal status of the peasant (farm) entity established as a legal entity must be determined by law. However, there is still no such law. Federal Law of 11 June 2003 No. 74-FZ "On Peasant (Farm) Economy" regulates only the features of the legal status of the respective farms that do not have the status of a legal entity. In practice, such regulation can create many difficulties when trying to reorganize the peasant (farm) entity that forms a legal entity.

Keywords: legal entity; commercial organization; corporation; peasant (farm) entity; reorganization; transformation; merger; accession; division; allocation.

Cite as: Gabov AV. Reorganizatsiya krestyanskogo (fermerskogo) khozyaystva - yuridicheskogo litsa [Reorganization of a Peasant (Farm) Entity Functioning as a Legal Entity]. Aktualnye problemy rossiyskogo prava. 2020;15(5):79-95. DOI: 10.17803/1994-1471.2020.114.5.079-095. (In Russ., abstract in Eng.).

$\Phi$ ормой осуществления семейного предпринимательства (в широком значении этого понятия) в постсоветской России является крестьянское (фермерское) хозяйство $^{1}$. Е. Л. Минина справедливо отмечает, что «аграрная и земельная реформы начала 90-х годов прошлого века в качестве одной из главных целей ставили создание условий для развития семейных ферм вместо крупных коллективных хозяйств ${ }^{2}$. На эту форму в конце $1980-x$ - начале 1990-х гг. экономисты и политики возлагали значительные надежды как на одно из средств, с помощью которых будет стимулироваться экономический рост (прежде всего в аграрном секторе). Недаром одним из первых законов, который был принят в рамках социально-экономических преобразований в России в нача- ле 1990-х гг., и, как отмечают исследователи, одним из первых актов, «посвященных аграрной и земельной реформе» ${ }^{3}$, стал Закон РСФСР от 22 ноября 1990 г. № 348-1 «О крестьянском (фермерском) хозяйстве» ${ }^{4}$ (далее - Закон о крестьянском (фермерском) хозяйстве 1990 г.).

Одним из основных положений этого нормативного акта было признание крестьянского (фермерского) хозяйства юридическим лицом: «Крестьянское (фермерское) хозяйство является самостоятельным хозяйствующим субъектом с правами юридического лица...» (ст. 1). Соответственно, как и любое юридическое лицо, крестьянское (фермерское) хозяйство могло быть реорганизовано. Время принятия Закона о крестьянском (фермерском) хозяйстве 1990 г. время становления современного правового ре-

1 Отдельные авторы говорят о «форме организации семейного бизнеса» (см.: Елкина О. С. Крестьянское (фермерское) хозяйство как форма организации семейного бизнеса // Вестник Московского университета МВД России. 2010. № 6. С. 104-108); можно встретить точку зрения о том, что крестьянское (фермерское) хозяйство - «это всегда семейно-трудовое объединение» (см.: Тютерева Н. Н. Актуальные проблемы правового положения крестьянского (фермерского) хозяйства // Право и экономика. 2018. № 12. С. 53-59).

2 Минина Е. Л. Проблемы правового регулирования статуса крестьянских (фермерских) хозяйств // Государство и бизнес в системе правовых координат : монография / А. В. Габов, В. Н. Литовкин, О. В. Гутников [и др.] ; отв. ред. А. В. Габов. М. : ИЗиСп; Инфра-М, 2014. С. 113.

3 Устюкова В. В. Гражданско-правовое регулирование создания и функционирования крестьянских (фермерских) хозяйств как субъектов предпринимательской деятельности // Предпринимательская деятельность в сельском хозяйстве России. Правовые вопросы / отв. ред. З. С. Беляева, И. А. Иконицкая. М. : ИГП РАН, 1998. С. 22.

4 Утратил силу в 2003 г. после принятия нового одноименного специального закона. 
гулирования реорганизации ${ }^{5}$ общие положения о реорганизации, равно как и положения о реорганизации для отдельных видов юридических лиц, были предельно лаконичными. Отсутствовали политико-правовые подходы и серьезные доктринальные разработки ${ }^{6}$ относительно того, как может/должно выглядеть описание реорганизации конкретного вида юридического лица в законе (ином нормативном правовом акте), в силу каких обстоятельств закон (иной акт) может содержать запреты (ограничения) на его реорганизацию (или реорганизацию в отдельных формах) и т.д.

Этот вывод хорошо может быть проиллюстрирован на примере Закона о крестьянском (фермерском) хозяйстве 1990 г.: в его тексте (в любой редакции) вообще не встречается слово "реорганизация". Данный Закон содержал специальный разд. VII «Прекращение деятельности фермерского хозяйства», включавший две статьи (32 и 33), в которых описывались условия и порядок прекращения деятельности такого хозяйства. Обратим внимание, что в этих статьях речь шла именно о прекращении деятельности, а не о прекращении самого юриди ческого лица - крестьянского (фермерского) хозяйства. Строго говоря, в данных положениях нет прямой связи между прекращением деятельности юридического лица и прекращением самого этого лица. Потому и описанные в ст. 32 указанного Закона случаи прекращения деятельности хозяйства выглядят весьма специфично. В данной статье было указано, что деятельность крестьянского хозяйства прекращается в случаях: а) неиспользования земельного участка в сельскохозяйственных целях в течение одного года; б) решения членов крестьянского хозяйства о прекращении его деятельности; в) если не остается ни одного члена хозяйства или наследника, желающего продолжать деятельность хозяйства; г) использования земельного участка методами, приводящими к деградации земли; д) изъятия земельного участка в установленном законом порядке для государственных и общественных нужд; е) в связи с банкротством. Иное изменение крестьянского (фермерского) хозяйства могло происходить только путем выхода из него одного или нескольких членов (ст. 15); такой выход также не признавался реорганизацией. Значимых исследований по этим проблемам не существует, а потому объяснить подходы законодателя вряд ли возможно.

Отсутствие внятного регулирования реорганизации отошло на задний план в связи с изменением подхода к регулированию крестьянских (фермерских) хозяйств после принятия ч. I Гражданского кодекса РФ. Согласно новым подходам крестьянское (фермерское) хозяйство не было признано видом юридического лица: п. 2 ст. 23 ГК РФ указывал, что глава крестьянского (фермерского) хозяйства, осуществляющего деятельность без образования юридического лица, признавался предпринимателем с момента государственной регистрации крестьянского (фермерского) хозяйства.

Принятие ч. I ГК РФ не прекратило автоматически существование ранее созданных крестьянских (фермерских) хозяйств - юридических лиц ${ }^{7}$. Однако такое изменение, надо отметить, даже породило судебную практику, когда

5 Подробнее см.: Габов А. В. Теория и практика реорганизации (правовой аспект). М., 2014. С. 77-102.

6 Исключая, пожалуй, только идею об универсальности правопреемства как последствия реорганизации, разработанную Б. Б. Черепахиным.

7 Строго говоря, Федеральный закон от 30 ноября 1994 г. № 52-Ф3 «О введении в действие части первой Гражданского кодекса Российской Федерации» о судьбе ранее созданных крестьянских (фермерских) хозяйств - юридических лиц вообще не говорил (см. ст. 6); в ст. 7 лишь содержалось указание на то, что при приведении правового положения таких хозяйств в соответствие с требованиями нового законодательства они освобождались от уплаты регистрационного сбора. Как отмечалось в специальной литературе, исходя из анализа судебной практики «сам факт изменения крестьянскими хозяйствами своего статуса не обусловливается никакими сроками; это зависит... лишь от желания самих фермеров» (см.: Устюкова В. В. Правовое положение крестьянского (фермерского) и личного подсобного хозяйства в условиях аграрной реформы. М. : ИГП РАН, 2000. С. 55). 
суды отказывали в ликвидации ранее созданных крестьянских (фермерских) хозяйств - юридических лиц с мотивировкой, что они не являются юридическими лицами после принятия ГК РФ, а потому их нельзя ликвидировать (см.: постановление ФАС Центрального округа от 15 октября 2003 г. по делу № A54-1632/03-C4); суды принимали также решения об отказе в ликвидации и по мотиву того, что такого основания прекращения деятельности нет в специальном законе - Законе о крестьянском (фермерском) хозяйстве 1990 г. (см.: постановление ФАС Центрального округа от 6 сентября 2002 г. № A14-3462-02/97/17). Понятно, что на фоне таких решений вопрос о реорганизации вообще перестал быть сколь-нибудь актуальным для крестьянских (фермерских) хозяйств - юридических лиц.

Правовое положение крестьянских (фермерских) хозяйств - юридических лиц, созданных в соответствии с Законом о крестьянском (фермерском) хозяйстве 1990 г., было определено статьей 23 Федерального закона от 11 июня 2003 г. № 74-Ф3 «О крестьянском (фермерском) хозяйстве» (далее - Закон о крестьянском (фермерском) хозяйстве 2003 г.). Такие хозяйства имели право сохранить статус юридического лица на период до 1 января 2010 г.; в последующем такое право было продлено до 1 января 2013 г. ${ }^{8}$, а затем - до 1 января 2021 г. ${ }^{9}$ Не менее важной являлась иная норма ст. 23 Закона о крестьянском (фермерском) хозяйстве 2003 г., установившая источники правового положения крестьянских (фермерских) хозяйств - юридических лиц: на такие хозяйства нормы Закона о крестьянском (фермерском) хозяйстве 2003 г., а также нормы иных нормативных правовых актов РФ, регулирующих деятельность крестьянских (фермерских) хозяйств, распространялись «постольку, поскольку иное не вытекает из федерального закона, иных нормативных правовых актов Российской Федерации или существа правоотношения».

Говоря иначе, на такие хозяйства можно было распространить общие положения о юридических лицах, а также учитывать специфику содержания их учредительных документов. В полной мере, конечно, такие положения ясности не вносили, но как минимум предоставляли возможность проводить реорганизацию, руководствуясь общими положениями гражданского законодательства ${ }^{10}$. В специальной литературе есть отдельные работы, в которых анализируются примеры реорганизации в тот период ${ }^{11}$; их изучение показывает, что количество проблемных вопросов при оценке законности реорганизации было весьма значительным.

Правовое положение крестьянского (фермерского) хозяйства претерпело радикальные изменения по итогам реформы гражданского законодательства ${ }^{12}$.

После принятия Федерального закона от 30 декабря 2012 г. № 302-Ф3 «О внесении изменений в главы 1, 2, 3 и 4 части первой Граж-

8 Федеральный закон от 30 октября 2009 г. № 239-Ф3 «О внесении изменения в статью 23 Федерального закона "О крестьянском (фермерском) хозяйстве"».

9 Федеральный закон от 25 декабря 2012 г. № 263-Ф3 «О внесении изменения в статью 23 Федерального закона "О крестьянском (фермерском) хозяйстве"».

10 Такую точку зрения можно встретить в работах профильных исследователей: Научно-практический комментарий к Гражданскому кодексу Российской Федерации : в 2 т. / под ред. Т. Е. Абовой, А. Ю. Кабалкина. 7-е изд., перераб. и доп. М. : Юрайт, 2012. Т. 1 : Части I, II ГК РФ. С. 274 (автор комментария к ст. 259 ГК РФ - В. В. Устюкова).

11 Мельников Н. Н. Правовое положение крестьянского (фермерского) хозяйства по законодательству России и СНГ / отв. ред. В. В. Устюкова. М. : Городец, 2010. С. 177-180.

12 См. также, например: Сафин 3. Ф. Новое в гражданско-правовом положении крестьянских (фермерских) хозяйств // Ученые записки Казанского университета. Серия : Гуманитарные науки. 2013. № 4. С. 151156 ; Молчанов А. А. Формирование правового статуса крестьянских (фермерских) хозяйств в свете реформы гражданского законодательства // Вестник Санкт-Петербургского университета МВД России. 2013. № 4 (60). С. 68-72; Устюкова В. В., Мельников Н. И. Развитие правового статуса крестьянского 
данского кодекса Российской Федерации» появилась возможность создания крестьянских (фермерских) хозяйств - юридических лиц. Новая статья 86.1 ГК РФ указала, что граждане, ведущие совместную деятельность в области сельского хозяйства без образования юридического лица на основе соглашения о создании крестьянского (фермерского) хозяйства, вправе создать юридическое лицо - крестьянское (фермерское) хозяйство. Согласно изменениям, внесенным Федеральным законом от 5 мая 2014 г. № 99-Ф3 «О внесении изменений в главу 4 части первой Гражданского кодекса Российской Федерации и о признании утратившими силу отдельных положений законодательных актов Российской Федерации», крестьянское (фермерское) хозяйство определено как одна из организационно-правовых форм, в которых могут создаваться юридические лица - коммерческие организации (ст. 50 ГК РФ).

Крестьянское (фермерское) хозяйство отнесено к корпорациям (ст. 65.1 ГК РФ); в ГК РФ эта новая корпорация заняла «промежуточное положение между хозяйственными товариществами и обществами ${ }^{13}$, не будучи отнесена ни к тому, ни к другому виду организаций, т.е., признана отдельной организационно-правовой формой. В профильной литературе по вопросу о месте крестьянского (фермерского) хозяйства после реформы высказаны иные точки зрения. Одни авторы полагают, что в виде хозяйства перед нами «особая разновидность хозяйственных товариществ» ${ }^{14}$. Другие исследователи считают, что по своим характеристикам крестьянское (фермерское) хозяйство - юридическое лицо ближе к кооперативу (высказано даже мнение, что, по существу, оно «представляет собой разновидность производственного кооператива $\left.{ }^{15}\right)$. Однако содержание ст. 50 ГК РФ не оставляет сомнений в том, что в настоящее время крестьянское (фермерское) хозяйство это самостоятельная организационно-правовая форма. При этом ее промежуточное положение между хозяйственными товариществами и хозяйственными обществами при отсутствии необходимого объема специального регули-

(фермерского) хозяйства в законодательстве России // Аграрное и земельное право. 2013. № 9 (105). С. 18-26; Минина Е. Л. Указ. соч. С. 112-120; Илюшина М. Н. Реформа ГК России: правовой статус крестьянского (фермерского) хозяйства // Законы России: опыт, анализ, практика. 2015. № 7. С. 36-39 ; Ельникова Е. В. Крестьянское (фермерское) хозяйство как субъект земельного рынка // Шестой Пермский конгресс ученых-юристов (г. Пермь, 16-17 октября 2015 г.) : избранные материалы / отв. ред. В. Г. Голубцов, О. А. Кузнецова. М. : Статут, 2016. С. 205-212 ; Микрюкова Г. А. О совершенствовании законодательства о крестьянских (фермерских) хозяйствах // Там же. С. 311-314; Майборода В. А. Правовое разграничение фермерского и крестьянского хозяйств применительно к формам корпоративного и индивидуального хозяйствования // Юрист. 2016. № 5. С. 20-24 ; Зинченко С. А. Об очередных попытках законодателя разрешить проблемы правового статуса крестьянского (фермерского) хозяйства // Там же. № 7. С. 32-35; Тагирова А. В. Правовой статус крестьянских (фермерских) хозяйств в условиях модернизации гражданского законодательства // Вестник Омской юридической академии. 2018. № 1. С. 107-111; Харитонова Ю. С. Правосубъектность крестьянского (фермерского) хозяйства в свете проблем права общей собственности его членов // Журнал предпринимательского и корпоративного права. 2018. № 2. С. 32-37; Попова О. В. Признаки крестьянского (фермерского) хозяйства // Юрист. 2018. № 5. С. 44-50; Тютерева Н. Н. Актуальные проблемы правового положения крестьянского (фермерского) хозяйства // Право и экономика. 2018. № 12. С. 53-59; Андреев Ю. Н. Юридические лица в гражданском праве России : монография. М. : Юрлитинформ, 2018. С. 309-315 ; Золотовская Е. А. К вопросу о гражданско-правовом статусе крестьянского (фермерского) хозяйства и правовом режиме его имущества // Административное и муниципальное право. 2019. № 2. С. 36-41.

13 Сафин З. Ф. Указ. соч. С. 153.

14 Устюкова В. В., Мельников Н. И. Указ. соч. С. 22 ; Суханов Е. А. Предпринимательские корпорации в новой редакции Гражданского кодекса Российской Федерации // Журнал российского права. 2015. № 1. С. 6.

15 Микрюкова Г. А. Указ. соч. С. 312. 
рования имеет существенное значение для регулирования различных аспектов создания, деятельности и прекращения крестьянского (фермерского) хозяйства - юридического лича.

Еще одним важным положением, внесенным Федеральным законом от 30 декабря 2012 г. № 302-Ф3 (ч. 7 ст. 2), стало указание на нормы, определяющие правовое положение крестьянских (фермерских) хозяйств, которые были созданы как юридические лица в соответствии с Законом о крестьянском (фермерском) хозяйстве 1990 г. К таким хозяйствам подлежат применению правила cm. 86.1 ГК РФ $\Phi^{16}$; при этом никакой перерегистрации ранее созданных крестьянских (фермерских) хозяйств не требовалось.

Можно констатировать, что в настоящее время сформирован общий правовой режим как для крестьянских (фермерских) хозяйств, созданных как юридические лица в соответствии с Законом о крестьянском (фермерском) хозяйстве 1990 г., так и для крестьянских (фермерских) хозяйств, созданных в соответcmвии со cm. 86.1 ГК РФ $\Phi^{17}$.

Такое регулирование нельзя в полной мере назвать определенным. По существу, оно предполагает наличие как минимум двух видов крестьянских (фермерских) хозяйств - юридических лиц:

- тех, что были созданы по Закону о крестьянском (фермерском) хозяйстве 1990 г. и чье имущество в соответствии со ст. 15 этого Закона принадлежит его членам на праве общей собственности;

- тех, что были созданы в соответствии со ст. 86.1 ГК РФ или привели свое правовое положение в соответствие с указанной статьей, чье имущество принадлежит, как и предусматривает эта статья, на праве собственности самому крестьянскому (фермерскому) хозяйству - юридическому лицу.

Такое видовое разнообразие может повлечь за собой при реорганизации множество сложных проблем.

Статья 86.1 ГК РФ предусматривает необходимость определения особенностей правового положения крестьянского (фермерского) хозяйства, созданного в качестве юридического лица, законом; тот же закон, видимо, мог бы решить вопрос и с собственностью таких хозяйств. Однако до сих пор соответствующий специальный акт не принят.

Исходя из этих выводов, посмотрим на регулирование вопросов реорганизации крестьянского (фермерского) хозяйства в настоящее время.

Статья 86.1 ГК РФ - единственный источник регулирования для крестьянского (фермерского) хозяйства - на возможность реорганизации такого хозяйства не указывает ${ }^{18}$.

Можно сказать, что такая особенность содержания ст. 86.1 ГК РФ не препятствует (не

16 Надо отметить, что поскольку не было отменено приведенное выше положение ст. 23 Закона о крестьянском (фермерском) хозяйстве 2003 г. о праве крестьянских (фермерских) хозяйств, которые были созданы как юридические лица в соответствии с Законом о крестьянском (фермерском) хозяйстве 1990 г., сохранить свой статус до 1 января 2021 г., то возникает некоторая двусмысленность в отношении дальнейшей судьбы таких хозяйств. Эту норму временного характера, очевидно, надо отменять.

17 Согласно данным ФНС России на 1 января 2020 г. в ЕГРЮЛ содержится информация о 6076 крестьянских (фермерских) хозяйствах - юридических лицах. Из них до 1 июля 2002 г. зарегистрированы 5148 хозяйств (т.е. можно считать, что это те самые хозяйства, созданные в соответствии с Законом о крестьянском (фермерском) хозяйстве 1990 г.); к этой цифре можно прибавить 264 хозяйства, которые были созданы до 18 марта 2014 г. на территории Республики Крым; таким образом, созданными уже по новым правилам ст. 86.1 ГК РФ предположительно (поскольку специальной статистики нет) можно считать 655 хозяйств, в том числе 652 - созданными путем учреждения (см.: URL: https://www.nalog.ru/rn77/related_activities/ statistics_and_analytics/forms/8376083/ (дата обращения: 6 марта 2020 г.)).

18 В литературе уже ставились вопросы в связи с этим о том, «в каком объеме нормы о реорганизации юридических лиц применимы к КФХ? Возможно ли преобразование КФХ в другую организационно-правовую форму?» (см.: Сафин 3. Ф. Указ. соч. С. 154). 
ограничивает в смысле ст. 57 ГК РФ) реорганизации крестьянского (фермерского) хозяйства - юридического лица в любой предусмотренной гражданским законодательством форме: слияние, присоединение, разделение, выделение, преобразование. Во-первых, в силу того, что никакого явного запрета (ограничения) для этого нет в самой статье. Во-вторых, в силу того, что вопросы реорганизации регулируются гражданским законодательством; возможность реорганизации - это часть корпуса общих положений о юридическом лице, по существу, мы можем говорить о праве юридического лица провести реорганизацию, а для ограничения такого - гражданского - права существуют специальные положения ст. 1 ГК РФ. Данная статья указывает, что гражданские права могут быть ограничены лишь на основании федерального закона и только в той мере, в какой это необходимо в целях защиты основ конституционного строя, нравственности, здоровья, прав и законных интересов других лиц, обеспечения обороны страны и безопасности государства. Ограничение (в качестве общего правила) возможности реорганизации крестьянского (фермерского) хозяйства - юридического лица не отвечает ни одной из указанных целей.

Однако такой вывод, с нашей точки зрения, нельзя признать в полной мере корректным. С одной стороны, общего запрета (ограничения) реорганизации действительно нет, с другой надо учитывать скрытые ограничения на ис- пользование большинства ее форм, вызванные содержанием сm. 86.1 ГК РФ.

Необходимо обратить внимание на регулирование создания крестьянского (фермерского) хозяйства - юридического лица в соответствии со ст. 86.1 ГК РФ. Согласно п. 1 этой статьи крестьянское (фермерское) хозяйство - юридическое лицо вправе создать «граждане, ведущие совместную деятельность в области сельского хозяйства без образования юридического лица на основе соглашения о создании крестьянского (фермерского) хозяйства». Формально это означает, что только указанная категория граждан - граждане, уже занимающиеся ${ }^{19}$ деятельностью в области сельского хозяйства без образования юридического лица на основе соглашения о создании крестьянского (фермерского) хозяйства, заключенного в соответствии с Законом о крестьянском (фермерском) хозяйстве 2003 г., (и никакие иные) - вправе создать крестьянское (фермерское) хозяйство - юридическое лицо.

Эту норму сегодня можно расценивать и как ограничение для иных граждан участвовать в таком хозяйстве. Но самое главное, что эту норму можно рассматривать как указание главного способа создания крестьянского (фермерского) хозяйства - юридического лица путем его учреждения ${ }^{20}$ указанными лицами и исключение реорганизации как способа создания ${ }^{21}$ (можно предположить, что данная норма имплицитно ограничивает возможность использования всех тех форм реорганизации,

19 В. А. Майборода справедливо отмечет: «Возможность создания КФХ в форме юридического лица без соглашения граждан, заключенного в соответствии с Законом “О крестьянском (фермерском) хозяйстве” 2003 г., законом не предполагается. КФХ - юридическое лицо возможно к созданию двумя этапами. Первый: заключение соглашения, регистрация крестьянского (фермерского) хозяйства по Закону 2003 г. в качестве КФХ, второй: регистрация этого КФХ в качестве юридического лица» (Майборода В. А. Правовое разграничение фермерского и крестьянского хозяйств применительно к формам корпоративного и индивидуального хозяйствования // Юрист. 2016. № 5. С. 20-24).

20 Здесь отметим, что вторым способом создания, возможным для крестьянского (фермерского) хозяйства - юридического лица, будет его восстановление в соответствии с правилами ст. 60.2 ГК РФ. Иные способы сегодня исключены.

21 На практике, видимо, эти правила иногда игнорируются; иначе как понимать статистику ФНС России, указывающую на создание 655 хозяйств, в том числе 652 - путем учреждения, а 3 - путем реорганизации (см.: URL: https://www.nalog.ru/rn77/related_activities/statistics_and_analytics/forms/8376083/ (дата обращения: 6 марта 2020 г.)). 
последствием которых является создание нового юридического лица). К таким формам сегодня, исходя из ст. 16 Федерального закона от 8 августа 2001 г. № 129-Ф3 «О государственной регистрации юридических лиц и индивидуальных предпринимателей», относятся:

- слияние (формула которого состоит в том, что два и более юридических лица прекращают свое существование и создается одно новое юридическое лицо);

- разделение (формула которого заключается в том, что одно лицо прекращается и создаются два и более новых юридических лица);

- выделение (формула которого заключается в том, что на основе имущества одного лица, не прекращающего существование в результате реорганизации, создается одно или несколько новых юридических лиц) $)^{22}$;
- преобразование (изменение организационно-правовой формы).

В части преобразования нельзя не заметить и еще одно: крестьянское (фермерское) хозяйство - юридическое лицо - одна из тех организационно-правовых форм юридического лица, преобразование которой в какое-либо иное лицо не предусмотрено ни в ГК РФ, ни в иных специальных законах. В нормативных актах, определяющих правовое положение иных юридических лиц, также ничего не сказано о возможности их преобразования, в свою очередь, в крестьянское (фермерское) хозяйство юридическое лицо ${ }^{23}$.

Такое регулирование однозначно исключает возможность участия крестьянского (рермерского) хозяйства - юридического лица в смешанной реорганизации, поскольку будет

22 В части выделения нельзя не отметить положения ст. 86.1 ГК РФ о том, что «гражданин может быть членом только одного крестьянского (фермерского) хозяйства, созданного в качестве юридического лица». Даже если не принимать во внимание невозможность выделения в силу специфики создания крестьянского (фермерского) хозяйства - юридического лица, отметим, что в совокупности с невозможностью преобразования (имеющего то последствие, что в результате гипотетического выделения могло быть создано только новое хозяйство) данное правило, в случае если выделение было бы разрешено, создавало бы значительные ограничения на формулирование его условий: лицу надо было бы выбирать - или остаться в реорганизуемом хозяйстве, или стать участником создаваемого хозяйства.

23 Здесь нельзя не сделать комментарий относительно ст. 10 Федерального закона от 8 декабря 1995 г. № 193-ФЗ «О сельскохозяйственной кооперации» (далее - Закон о сельскохозяйственной кооперации). Согласно ей «при образовании в результате реорганизации сельскохозяйственной организации наряду с производственным кооперативом иных коммерческих сельскохозяйственных организаций, крестьянских (фермерских) хозяйств разделу не подлежат объекты производственной инфраструктуры (в том числе мастерские по ремонту техники, гаражи, сушилки для зерна и других сельскохозяйственных культур, тока, склады), услугами которых пользовались члены (участники) реорганизуемой сельскохозяйственной организации». В такой редакции эта норма существует после принятия Федерального закона от 11 июня 2003 г. № 73-Ф3 «О внесении изменений и дополнений в Федеральный закон “О сельскохозяйственной кооперации" ». То есть этот Закон принимался одновременно с Законом о крестьянском (фермерском) хозяйстве 2003 г. Интересно, что пояснительная записка к проекту федерального закона № 158978-3 "О внесении изменений и дополнений в Федеральный закон “О сельскохозяйственной кооперации"» (который стал впоследствии Федеральным законом от 11 июня 2003 г. № 73-Ф3) вообще предлагала «исключить статью 10 как морально устаревшую». Однако в итоге она была изложена в новой редакции, появилось и это правило. Пояснить его цель в точности невозможно; но можно предположить, что правило было рассчитано на случаи преобразования крестьянских (фермерских) хозяйств, созданных как юридические лица в соответствии с Законом о крестьянском (фермерском) хозяйстве 1990 г., и ни на какие иные случаи. Использовать это правило в настоящее время для обоснования возможности преобразования как указанных крестьянских (фермерских) хозяйств, так и крестьянских (фермерских) хозяйств, созданных в соответствии со ст. 86.1 ГК РФ, не представляется возможным в силу того, что оно не соответствует обновленным по итогам реформы положениям ГК РФ (ст. 86.1). Кроме того, следует 
нарушено правило п. 1 ст. 57 ГК РФ, в соответствии с которым допускается реорганизация с участием двух и более юридических лиц, в том числе созданных в разных организационно-правовых формах, если ГК РФ или другим законом предусмотрена возможность преобразования юридического лица одной из таких организационно-правовых форм в юридическое лицо другой из таких организационно-правовых форм 24 .

Этого ли эффекта - невозможности использования практически всех форм реорганизации - добивались авторы ст. 86.1 ГК РФ, сказать сложно, ибо никаких пояснений, обосновывающих ее введение в ГК РФ в таком виде, мы не находим. Но если принять указанную гипотезу (а именно на этом мы и настаиваем), то можно сделать следующий вывод: на сегодняшний день единственной доступной для крестьянского (фермерского) хозяйства - юридического лица формой реорганизации является присоединение.
Однако как проводить такое присоединение, если ст. 86.1 ГК РФ не содержит никаких правил о порядке проведения реорганизации? ${ }^{25}$ Наиболее простым ответом будет следующий: на основании общих положений о реорганизации юридического лица, сформулированных в ст. 57-60.2 ГК РФ. Такой ответ, впрочем, не будет точным: дело в том, что эти общие правила не содержат ответов на множество важных вопросов (к примеру, что делать с долями участия). Отсюда возникает вопрос о возможности применения положений, регулирующих сходные отношения. И вот здесь надо вспомнить о том, что нормы о крестьянском (фермерском) хозяйстве - юридическом лице помещены между хозяйственными товариществами и обществами (см. выше). Какой аналогией воспользоваться: использовать регулирование, применяемое для товариществ или применяемое для обществ ${ }^{26}$

По своей природе хозяйства явно ближе к товариществам (преобладание личных элемен-

обратить внимание на юридическую технику ст. 10 Закона о сельскохозяйственной кооперации - она не указывает однозначно на возможность преобразования; слова «при образовании в результате реорганизации... крестьянских (фермерских) хозяйств», по существу, представляют собой правило, которое действует в случае, если такое преобразование предусмотрено законом. Не может быть использовано в качестве аргумента и положение ст. 41 Закона о сельскохозяйственной кооперации, согласно которой, «если разделительный баланс не дает возможности определить правопреемника реорганизованного кооператива, вновь возникшие юридические лица и крестьянские (фермерские) хозяйства несут солидарную ответственность по обязательствам реорганизованного кооператива перед его кредиторами».

24 Подробнее см.: Габов А. В. Реорганизация и ликвидация юридических лиц : научно-практический комментарий к статьям 57-65 Гражданского кодекса Российской Федерации. М. : ИЗиСП при Правительстве РФ: Инфра-М, 2014. С. 10-13.

25 Перед нами, таким образом, классический случай пробела - т.е. ситуации, когда отсутствует юридическая норма, «которая должна быть в системе права с точки зрения предмета правового регулирования, его объема и содержания» (см.: Власенко Н. А. Проблемы правовой неопределенности : курс лекций. М. : ИЗиСП при Правительстве РФ: Инфра-М, 2015. С. 65), отсутствует «необходимое звено в системе юридического воздействия на общественные отношения» (см.: Спектор Е. И. Проблемы в законодательстве и пути их преодоления : автореф. дис. ... канд. юрид. наук. М., 2003. С. 5). Институционализация организационно-правовой формы юридического лица предполагает, что нормативные положения, регулирующие правовое положение юридического лица соответствующей организационно-правовой формы, должны однозначно определять возможность (или запрет) реорганизации, и в случае отсутствия прямого запрета - устанавливать особенности реорганизации.

26 Отметим, что в некоторых источниках высказана крайне критическая точка зрения о применении аналогии с хозяйственными товариществами и обществами. К примеру, Е. В. Ельникова пишет: «Распространять на КФХ общие положения о хозяйственных товариществах и обществах нет никаких оснований. В результате возникают сомнения в жизнеспособности конструкции КФХ как юридического лица, возможности 
тов $^{27}$ ), на что обращают внимание и отдельные исследователи ${ }^{28}$; однако в части реорганизации хозяйственных товариществ регулирование порядка реорганизации отсутствует.

Таким образом, источником «заимствования» регулирования может быть законодательство об обществах с ограниченной ответственность $^{29}$, где вопросам порядка реорганизации уделено определенное внимание ${ }^{30}$ (ст. 8, 33, 37, 45, 46, 51-56 Федерального закона от 8 февраля 1998 г. № 14-Ф3 «Об обществах с ограниченной ответственностью» (далее - Закон об обществах с ограниченной ответственностью)).

В практике имеются примеры (в части регулирования вопросов доступа членов крестьян- ского (фермерского) хозяйства - юридического лица к информации о его деятельности), показывающие использование судами положений законодательства об обществах с ограниченной ответственностью ${ }^{31}$ (постановление Арбитражного суда Дальневосточного округа от 11 декабря 2019 г. № Ф03-5888/2019 по делу № A04-498/201932). В указанном судебном акте участник крестьянского (фермерского) хозяйства - юридического лица, созданного в соответствии с Законом о крестьянском (фермерском) хозяйстве 1990 г., требовал от хозяйства информацию. Суд отметил со ссылкой на п. 6 ст. 13 АПК РФ: «В случаях, когда спорные отношения прямо не урегулированы федеральным

создания новых субъектов в этой организационно-правовой форме, по крайней мере до тех пор, пока законодатель не завершил процесс ее окончательной инкорпорации в систему юридических лиц» (Ельникова Е. В. Указ. соч. С. 208). С нашей точки зрения, такой подход не может быть поддержан, ибо жизнь не стоит на месте, требуется регулирование различных отношений, возникающих в связи с деятельностью, реорганизацией крестьянских (фермерских) хозяйств, ждать, когда законодатель что-то куда-то инкорпорирует, - значит отказывать участникам правоотношений в возможности удовлетворения их интересов, и при отсутствии регулирования аналогия - не худший вариант.

27 Подробнее о так называемых «личных элементах», об их значении для формообразования юридических лиц см.: Габов А. В. Общества с ограниченной и дополнительной ответственностью в российском законодательстве. М. : Статут, 2010. С. 43-90; Юридические лица в гражданском праве : Юридические лица в российском гражданском праве (коммерческие и некоммерческие организации) / отв. ред. В. Н. Литовкин, О. В. Гутников. М. : ИЗиСП при Правительстве РФ, 2011. С. 223-233 (автор главы - А. В. Габов).

28 См.: Андреев Ю. Н. Указ. соч. С. 314.

29 Вопрос в том, единственным ли, поскольку в практике имеются дела, в которых суды иногда «заимствуют» регулирование и из законодательства о сельскохозяйственной кооперации. Причем бывает так, что в одном судебном акте можно встретить пример заимствования и из законодательства об обществах с ограниченной ответственностью, и из законодательства о сельскохозяйственной кооперации (см.: постановление Пятнадцатого арбитражного апелляционного суда от 17 декабря 2018 г. № 15АП-9137/2018 по делу № А53-25854/2017). Кроме того, как думается, в некоторых случаях можно ставить вопрос и об аналогии с нормами Закона о крестьянском (фермерском) хозяйстве 2003 г.

30 Хотя, строго говоря, даже в совокупности с судебной практикой в части положений о реорганизации данный Закон очень беден.

31 Справедливости ради отметим, что имеется и иная практика, когда суды отказываются использовать аналогию. Приводивший указанный пример (дело касалось исключения участника хозяйства) В. А. Микрюков отмечает, что такая практика мотивирована «идеей об исключительности каждой из предусмотренных законом моделей коммерческих корпораций и посылом о недопустимости ограничения гражданских прав на основании аналогии при отсутствии на то прямого указания закона» (Микрюков В. А. Аналогия в механизме моделирования юридической личности крестьянского (фермерского) хозяйства // Шестой Пермский конгресс ученых-юристов. С. 310-311).

32 URL: http://kad.arbitr.ru/Document/Pdf/4c001e3d-63aa-41ff-ae8d-0d3669d1061a/f94c43b6-6013-4050-958f49aabe3a8b6d/A04-498-2019_20191211_Postanovlenie_kassacionnoj_instancii.pdf?isAddStamp=True (дата обращения: 5 марта 2020 г.). 
законом и другими нормативными актами или соглашением сторон и отсутствует применимый к ним обычай делового оборота, к таким отношениям, если это не противоречит их существу, арбитражные суды применяют нормы права, регулирующие сходные отношения. Поскольку нормами Закона № 348-1 (суд имел в виду Закон о крестьянском (фермерском) хозяйстве 1990 г. - Прим. А. Г.) не урегулирован порядок предоставления участнику крестьянско-фермерского хозяйства бухгалтерской и иной документации, суды правомерно применили к рассматриваемым правоотношениям по аналогии положения Федерального закона от 08.02.1998 № 14-Ф3 "Об обществах с ограниченной ответственностью"». Не останавливаясь на некоторых ошибках в виде ссылки на недействующий акт - Закон о крестьянском (фермерском) хозяйстве 1990 г., тем не менее отметим, что сам факт обращения к законодательству об обществах с ограниченной ответственностью может быть оценен с осторожным позитивом. При отсутствии не то что внятного, а вообще какого-либо регулирования такое решение явно не худшее для целей обеспечения прав и законных интересов участников крестьянского (фермерского) хозяйства - юридического лица. Так, в качестве аналогии можно было бы использовать правило единогласия всех членов как присоединяющего, так и присоединяемого крестьянского (фермерского) хозяйства - юридического лица.

Однако такой прием (аналогия) не способен, как это ни покажется парадоксальным, решить все проблемы, ибо они не решены и в Законе об обществах с ограниченной ответственностью.
В частности, речь идет о судьбе долей участников общества с ограниченной ответственностью при реорганизации. Этот важнейший вопрос непосредственно в Законе об обществах с ограниченной ответственностью не урегулирован должным образом, если не сказать больше . $^{33}$. Применительно же к крестьянскому (фермерскому) хозяйству - юридическому лицу проблема с определением судьбы долей участников при реорганизации осложняется тем, что законодатель о таких долях не упоминает вовсе. Статья 86.1 ГК РФ лишь констатирует, что в виде крестьянского (фермерского) хозяйства - юридического лица перед нами объединение граждан «на основе членства». Однако содержание этого «членства» не раскрывается: в какой правовой форме такое членство оформлено (доля, как в обществе с ограниченной ответственностью, пай или что-то еще), может ли это «нечто», оформляющее членские права, отчуждаться или оно неотчуждаемо? На эти, как и на любые иные, вопросы ответов нет. А ведь без них невозможно понять, что происходит (должно происходить) с членскими правами участников хозяйства в результате реорганизации (особенно учитывая многообразие моделей членства, которое предусматривает действующее законодательство $\left.{ }^{34}\right)$. Особенную остроту этот вопрос может приобрести в случае с крестьянскими (фермерскими) хозяйствами, которые были созданы как юридические лица в соответствии с Законом о крестьянском (фермерском) хозяйстве 1990 г., уставы которых могут предусматривать общую собственность их участников на имущество таких хозяйств ${ }^{35}$

33 Отчасти проблему восполняет судебная практика (к примеру, см.: постановление Арбитражного суда Дальневосточного округа от 10 ноября 2017 г. № Ф03-3700/2017 по делу № А51-6270/201), однако в отдельных аспектах и она носит противоречивый характер.

34 Подробнее см.: Корпоративное право : учебный курс : в 2 т. / отв. ред. И. С. Шиткина. М. : Статут, 2017. Т. 1. С. 585-587 (автор главы - А. В. Габов).

35 Хотя здесь нельзя не отметить некоторые правовые позиции судов, указывающих ни много ни мало, что в результате реформы гражданского законодательства отношения собственности в крестьянских (фермерских) хозяйствах изменились автоматически: «С 31.12.2012 в силу нормативного правового регулирования крестьянское (фермерское) хозяйство, являющееся юридическим лицом, стало собственником имущества, а члены хозяйства утратили в отношении указанного имущества вещные права (право собственности), приобретя корпоративные права» (постановление Арбитражного суда Северо-Кавказского округа от 21 марта 2019 г. по делу № A53-25854/2017). 
Формально, обращаясь к Закону о крестьянском (фермерском) хозяйстве 2003 г., можно отметить, что участники крестьянского (фермерского) хозяйства, не являющегося юридическим лицом, имеют экономический интерес в его деятельности. В определенных случаях (при долевой собственности на имущество фермерского хозяйства) соглашением о создании фермерского хозяйства (ст. 4 указанного Закона) между участниками такого хозяйства определяются их доли в имуществе; участники (члены) имеют право выхода из фермерского хозяйства (ст. 6) по заявлению (ст. 14); каждый член фермерского хозяйства имеет право на часть доходов, полученных от деятельности фермерского хозяйства в денежной и (или) натуральной форме, плодов, продукции; размер и форма выплаты каждому члену фермерского хозяйства дохода определяются по соглашению между членами фермерского хозяйства (ст. 15); гражданин в случае выхода из фермерского хозяйства имеет право на денежную компенсацию, соразмерную его доле в праве общей собственности на имущество фермерского хозяйства (ст. 9). По существу, перед нами несколько измененная (для учета специфики правового положения такого хозяйства) модель взаимоотношений между участником общества с ограниченной ответственностью и таким обществом.

Следовательно, используя аналогию с нормами Закона о крестьянском (фермерском) хозяйстве 2003 г. и учитывая, что по логике ст. 86.1 ГК РФ основой создаваемого крестьянского (фермерского) хозяйства - юридического лица будет (хотя прямой корреляции, конечно, здесь нет) соглашение между членами действующего крестьянского (фермерского) хозяйства, не являющегося юридическим лицом, можно предположить, что в случае прекращения присоединяемого крестьянского (фермерского) хозяйства - юридического лица его участники должны получить компенсацию за утрату участия.
Однако в чем эта компенсация может выражаться? В теории можно выделить различные формы компенсации: 1) предоставление денежных средств; 2) передача в собственность ценных бумаг, иных, кроме закрепляющих права участия (данная форма актуальна для реорганизации акционерных обществ); 3) предоставление права участия в создаваемом в результате реорганизации юридическом лице ${ }^{36}$. Применительно к обществам с ограниченной ответственностью и крестьянским (фермерским) хозяйствам - юридическим лицам речь может идти об использовании первой и третьей формы.

Закон об обществах с ограниченной ответственностью в положениях о реорганизации возможности компенсации утраты участия денежными средствами (в отличие от законодательства об акционерных обществах (в виде выкупа акций)) не предусматривает.

В судебной практике имеются редкие примеры предоставления денежной компенсации в виде погашения доли участия лиц в прекращаемых путем присоединения обществах с ограниченной ответственностью (см.: постановление Арбитражного суда Поволжского округа от 1 апреля 2015 г. № Ф06-21950/2013 по делу № A12-24178/2014). Однако имеется и совершенно противоположная практика - исключающая предоставление денежной компенсации. Кроме того, отметим, что приведенное дело, строго говоря, противоречит Закону об обществах с ограниченной ответственностью в части реорганизации, который, как уже было отмечено, не предусматривает денежной компенсации. Поэтому можно с большой долей уверенности утверждать, что в настоящее время при реорганизации общества с ограниченной ответственностью компенсация утраты участия может носить только характер предоставления доли участия в присоединяющем обществе с ограниченной ответственностью ${ }^{37}$.

Как все это применить в случае реорганизации в форме присоединения одного крестьян-

36 См.: Габов А. В. Теория и практика реорганизации (правовой аспект). С. 772-775.

37 Отметим, что такая модель компенсации не кажется нам в полной мере справедливой; по существу, она ограничивает участников общества с ограниченной ответственностью в выборе вариантов компенсации при наличии общей договоренности, хотя в современных условиях гарантирует права участников от 
ского (фермерского) хозяйства - юридического лица к другому?

Нам представляется, что, учитывая отсутствие каких-либо ограничений, а также исходя из принципа диспозитивности регулирования, целесообразно при общем требовании обязательности компенсации утрачиваемого участия исходить из возможности как денежной компенсации (своего рода аналог выхода из членов хозяйства), так и компенсации в форме предоставления права участия в присоединяющем крестьянском (фермерском) хозяйстве юридическом лице.

Однако такая альтернатива может иметь место только при добровольности выбора участника прекращаемого в результате присоединения хозяйства и при отсутствии фрактов введения его в заблуждение относительно условий реорганизации и оценки перспектив деятельности присоединяющего хозяйства после окончания реорганизации.

В любом случае вопрос о применимости такой альтернативы сегодня будут решать при завершении реорганизации (при рассмотрении документов, направленных на государственную регистрацию) регистрирующие органы (исходя из пп. «Х» п. 1 ст. 23 Федерального закона от 8 августа 2001 г. № 129-Ф3 «О государственной регистрации юридических лиц и индивидуальных предпринимателей»), а в конечном итоге суд.

Подводя итоги исследования, отметим, что текущее правовое регулирование вопросов реорганизации крестьянского (фермерского) хозяйства - юридического лица является отражением общего состояния регулирования этой организационно-правовой формы. Оно характеризуется «подвешенным» состоянием: возможность создавать новые хозяйства есть, но никакого регулирования нет; установлена необходимость применения к ранее созданным хозяйствам новых положений ст. 86.1 ГК РФ, но как соизмерять новые нормы с текущим состоянием уставов таких организаций, не определено.
Ничего не слышно и о разработке специального закона, которым будет регулироваться создание, деятельность и прекращение крестьянского (фермерского) хозяйства - юридического лица (или о дополнении соответствующими положениями Закона о крестьянском (фермерском) хозяйстве 2003 г.).

В 2013 г. ряд депутатов Государственной Думы внесли проект федерального закона "О внесении изменений в Федеральный закон “О крестьянском (фермерском) хозяйстве"» (№ 256199-6) $)^{38}$. Этот законопроект интересующим нас в данной работе вопросам внимания уделял мало. В части реорганизации он предлагал переименовать ст. 21 Закона о крестьянском (фермерском) хозяйстве 2003 г. - «Основания прекращения фермерского хозяйства и его преобразование», а также дополнить эту статью в части реорганизации всего одним пунктом следующего содержания: «3. Реорганизация крестьянского (фермерского) хозяйства, созданного гражданами, ведущими совместную деятельность в области сельского хозяйства без образования юридического лица на основе соглашения о создании крестьянского (фермерского) хозяйства, в юридическое лицо - крестьянское (фермерское) хозяйство осуществляется без прекращения их деятельности до завершения процедуры реорганизации. Созданное юридическое лицо - крестьянское (фермерское) хозяйство является правопреемником реформированного крестьянского (фермерского) хозяйства, осуществлявшего предпринимательскую деятельность без образования юридического лица».

Иных положений, собственно о реорганизации крестьянского (фермерского) хозяйства - юридического лица, данный проект не содержал. Предлагавшиеся же изменения были оригинальны; по существу, они, не решая базовых вопросов реорганизации крестьянского (фермерского) хозяйства - юридического лица, предполагали совершенно иное понимание реорганизации, нежели то, которое закрепляла

попыток «выбросить» их из участия в обществе с ограниченной ответственностью. Конечно, нам представляется, что в будущем этот вопрос должен быть решен в законе более гибко.

38 Cм.: URL: https://sozd.duma.gov.ru/bill/256199-6 (дата обращения: 10 марта 2020 г.). 
статья 57 ГК РФ (допущение института реорганизации к организациям, не являвшимся юридическими лицами ${ }^{39}$ ).

Законопроект был отклонен Государственной Думой, что нельзя не поддержать, учитывая «убогость» его содержания даже в таком узком вопросе, как реорганизация. Однако с тех пор никаких иных законопроектов по данному вопросу не внесено. Закон же - или специальный закон, или закон, дополняющий действующий Закон о крестьянском (фермерском) хозяйстве 2003 г., - должен быть принят как можно скорее. Необходимо также принять закон об изменении ст. 86.1 ГК РФ, ибо ее положения не в полной мере определенны, а цель появления и существования некоторых из них (в части создания крестьянского (фермерского) хозяйства юридического лица) в нынешнем виде не ясна. Реорганизация крестьянского (фермерского) хозяйства - юридического лица, вне всяких сомнений, имеет свою специфику, однако она не должна приводить к фактической невозможности реорганизации такого вида юридического лица. Закон должен детально урегулировать вопросы реорганизации этого вида юридического лица с учетом такой специфики, а также учитывая опыт развития правового регулирования реорганизации иных юридических лиц - корпораций, прежде всего акционерного общества и общества с ограниченной ответственностью.

\section{БИБЛИОГРАФИЯ}

1. Аграрное право России : учебник / рук. авт. кол. и отв. ред. М. И. Козырь. - М. : Норма : Инфра-М, 2010. - $608 \mathrm{c}$.

2. Андреев Ю. Н. Юридические лица в гражданском праве России : монография. - М. : Юрлитинформ, 2018. - 376 c.

3. Власенко Н. А. Проблемы правовой неопределенности : курс лекций. - М. : ИЗиСП при Правительстве РФ: Инфра-М, 2015. - 176 с.

4. Габов А. В. Общества с ограниченной и дополнительной ответственностью в российском законодательстве. - М. : Статут, 2010. - 253 с.

5. Габов А. В. Теория и практика реорганизации (правовой аспект). - М. : Статут, 2014. - 880 с.

6. Габов А. В. Реорганизация и ликвидация юридических лиц : научно-практический комментарий к статьям 57-65 Гражданского кодекса Российской Федерации. - М. : ИЗиСП при Правительстве РФ: Инфра-М, 2014. - 203 с.

7. Елкина О. С. Крестьянское (фермерское) хозяйство как форма организации семейного бизнеса // Вестник Московского университета МВД России. - 2010. - № 6. - С. 104-108.

8. Ельникова Е. В. Крестьянское (фермерское) хозяйство как субъект земельного рынка // Шестой Пермский конгресс ученых-юристов (г. Пермь, 16-17 октября 2015 г.) : избранные материалы / отв. ред. В. Г. Голубцов, О. А. Кузнецова. - М. : Статут, 2016. - С. 205-212.

9. Зинченко С. А. Об очередных попытках законодателя разрешить проблемы правового статуса крестьянского (фермерского) хозяйства // Юрист. - 2016. - № 7. - С. 32-35.

10. Золотовская Е. А. К вопросу о гражданско-правовом статусе крестьянского (фермерского) хозяйства и правовом режиме его имущества // Административное и муниципальное право. - 2019. - № 2. C. $36-41$.

11. Илюшина М. Н. Реформа ГК России: правовой статус крестьянского (фермерского) хозяйства // Законы России: опыт, анализ, практика. - 2015. - № 7. - С. 36-39.

39 Отметим, что в отдельных работах, посвященных проблемам правового положения крестьянских (фермерских) хозяйств, такие идеи ранее высказывались (к примеру, см.: Аграрное право России : учебник / рук. авт. кол. и отв. ред. М. И. Козырь. М. : Норма : Инфра-М, 2010. С. 258 (автор главы - В. В. Устюкова). 
12. Корпоративное право : учебный курс : в 2 т. / отв. ред. И. С. Шиткина. - М., Статут, 2017. - Т. 1. $976 \mathrm{c}$.

13. Майборода В. А. Правовое разграничение фермерского и крестьянского хозяйств применительно к формам корпоративного и индивидуального хозяйствования // Юрист. - 2016. - № 5. - С. $20-24$.

14. Мельников Н. Н. Правовое положение крестьянского (фермерского) хозяйства по законодательству России и СНГ / отв. ред. В. В. Устюкова. - М. : Городец, 2010. - 400 с.

15. Микрюков В. А. Аналогия в механизме моделирования юридической личности крестьянского (фермерского) хозяйства // Шестой Пермский конгресс ученых-юристов (г. Пермь, 16-17 октября 2015 г.) : избранные материалы / отв. ред. В. Г. Голубцов, О. А. Кузнецова. - М. : Статут, 2016. - С. 306-311.

16. Микрюкова Г. А. О совершенствовании законодательства о крестьянских (фермерских) хозяйствах // Шестой Пермский конгресс ученых-юристов (г. Пермь, 16-17 октября 2015 г.) : избранные материалы / отв. ред. В. Г. Голубцов, О. А. Кузнецова. - М. : Статут, 2016. - С. 311-314.

17. Минина Е. Л. Проблемы правового регулирования статуса крестьянских (фермерских) хозяйств // Государство и бизнес в системе правовых координат : монография / А. В. Габов, В. Н. Литовкин, О. В. Гутников [и др.] ; отв. ред. А. В. Габов. - М. : ИЗиСп; Инфра-М, 2014. - С. 112-120.

18. Молчанов А. А. Формирование правового статуса крестьянских (фермерских) хозяйств в свете реформы гражданского законодательства // Вестник Санкт-Петербургского университета МВД России. - 2013. № 4 (60) . - С. 68-72.

19. Научно-практический комментарий к Гражданскому кодексу Российской Федерации : в 2 т. / под ред. Т. Е. Абовой, А. Ю. Кабалкина. - 7-е изд., перераб. и доп. - М. : Юрайт, 2012. - Т. 1 : Части I, II ГК РФ. - 923 с.

20. Попова О. В. Признаки крестьянского (фермерского) хозяйства // Юрист. - 2018. - № 5. - С. 44-50.

21. Сафин 3. Ф. Новое в гражданско-правовом положении крестьянских (фермерских) хозяйств // Ученые записки Казанского университета. Серия : Гуманитарные науки. - 2013. - № 4. - С. 151-156.

22. Спектор Е. И. Проблемы в законодательстве и пути их преодоления : автореф. дис. ... канд. юрид. наук. - М., 2003. - 21 с.

23. Суханов Е. А. Предпринимательские корпорации в новой редакции Гражданского кодекса Российской Федерации // Журнал российского права. - 2015. - № 1. - С. 5-13.

24. Тагирова А. В. Правовой статус крестьянских (фермерских) хозяйств в условиях модернизации гражданского законодательства // Вестник Омской юридической академии. - 2018. - № 1. - С. $107-111$.

25. Тютерева Н. Н. Актуальные проблемы правового положения крестьянского (фермерского) хозяйства // Право и экономика. - 2018. - № 12. - С. 53-59.

26. Устюкова В. В. Гражданско-правовое регулирование создания и функционирования крестьянских (фермерских) хозяйств как субъектов предпринимательской деятельности // Предпринимательская деятельность в сельском хозяйстве России. Правовые вопросы / отв. ред. З. С. Беляева, И. А. Иконицкая. - М. : Институт государства и права РАН, 1998. - С. 22-38.

27. Устюкова В. В. Правовое положение крестьянского (фермерского) и личного подсобного хозяйства в условиях аграрной реформы. - М. : Институт государства и права РАН, 2000. - 192 с.

28. Устюкова В. В., Мельников Н. И. Развитие правового статуса крестьянского (фермерского) хозяйства в законодательстве России // Аграрное и земельное право. - 2013. - № 9 (105). - С. 18 -26.

29. Харитонова Ю. С. Правосубъектность крестьянского (фермерского) хозяйства в свете проблем права общей собственности его членов // Журнал предпринимательского и корпоративного права. - 2018. № 2. - С. 32-37.

30. Юридические лица в гражданском праве : Юридические лица в российском гражданском праве (коммерческие и некоммерческие организации) / отв. ред. В. Н. Литовкин, О. В. Гутников. - М. : ИЗиСП при Правительстве РФ, 2011. - 1024 с. 


\section{REFERENCES (TRANSLITERATION)}

1. Agrarnoe pravo Rossii : uchebnik / ruk. avt. kol. i otv. red. M. I. Kozyr. - M. : Norma : Infra-M, 2010. - 608 s.

2. Andreev Yu. N. Yuridicheskie licza v grazhdanskom prave Rossii : monografiya. - M. : Yurlitinform, 2018. $376 \mathrm{~s}$.

3. Vlasenko N. A. Problemy pravovoj neopredelennosti : kurs lekcij. - M. : IZiSP pri Pravitelstve RF: Infra-M, 2015. $-176 \mathrm{~s}$.

4. Gabov A. V. Obshhestva s ogranichennoj i dopolnitelnoj otvetstvennostyu v rossijskom zakonodatelstve. M. : Statut, 2010. $-253 \mathrm{~s}$.

5. Gabov A. V. Teoriya i praktika reorganizacii (pravovoj aspekt). - M. : Statut, 2014. - $880 \mathrm{~s}$.

6. Gabov A. V. Reorganizaciya i likvidaciya yuridicheskix licz : nauchno-prakticheskij kommentarij k statyam 57-65 Grazhdanskogo kodeksa Rossijskoj Federacii. - M. : IZiSP pri Pravitelstve RF: Infra-M, 2014. - 203 s.

7. Elkina O. S. Krestyanskoe (fermerskoe) xozyajstvo kak forma organizacii semejnogo biznesa // Vestnik Moskovskogo universiteta MVD Rossii. - 2010. - № 6. - S. 104-108.

8. Elnikova E. V. Krestyanskoe (fermerskoe) xozyajstvo kak subekt zemelnogo rynka // Shestoj Permskij kongress uchenyx-yuristov (g. Perm, 16-17 oktyabrya 2015 g.) : izbrannye materialy / otv. red. V. G. Golubczov, O. A. Kuzneczova. - M. : Statut, 2016. - S. 205-212.

9. Zinchenko S. A. Ob ocherednyx popytkax zakonodatelya razreshit problemy pravovogo statusa krestyanskogo (fermerskogo) xozyajstva // Yurist. - 2016. - № 7. - S. 32-35.

10. Zolotovskaya E. A. K voprosu o grazhdansko-pravovom statuse krestyanskogo (fermerskogo) xozyajstva i pravovom rezhime ego imushhestva // Administrativnoe i municipalnoe pravo. - 2019. - № 2. - S. 36-41.

11. Ilyushina M. N. Reforma GK Rossii: pravovoj status krestyanskogo (fermerskogo) xozyajstva // Zakony Rossii: opyt, analiz, praktika. - 2015. - № 7. - S. 36-39.

12. Korporativnoe pravo : uchebnyj kurs : v 2 t. / otv. red. I. S. Shitkina. - M., Statut, 2017. - T. 1. - 976 s.

13. Majboroda V. A. Pravovoe razgranichenie fermerskogo i krestyanskogo xozyajstv primenitelno $\mathrm{k}$ formam korporativnogo i individualnogo xozyajstvovaniya // Yurist. - 2016. - № 5. - S. 20-24.

14. Melnikov N. N. Pravovoe polozhenie krestyanskogo (fermerskogo) xozyajstva po zakonodatelstvu Rossii i SNG / otv. red. V. V. Ustyukova. - M. : Gorodecz, 2010. - 400 s.

15. Mikryukov V. A. Analogiya v mexanizme modelirovaniya yuridicheskoj lichnosti krestyanskogo (fermerskogo) xozyajstva // Shestoj Permskij kongress uchenyx-yuristov (g. Perm, 16-17 oktyabrya 2015 g.) : izbrannye materialy / otv. red. V. G. Golubczov, O. A. Kuzneczova. - M. : Statut, 2016. - S. 306-311.

16. Mikryukova G. A. O sovershenstvovanii zakonodatelstva o krestyanskix (fermerskix) xozyajstvax // Shestoj Permskij kongress uchenyx-yuristov (g. Perm, 16-17 oktyabrya 2015 g.) : izbrannye materialy / otv. red. V. G. Golubczov, O. A. Kuzneczova. - M. : Statut, 2016. - S. 311-314.

17. Minina E. L. Problemy pravovogo regulirovaniya statusa krestyanskix (fermerskix) xozyajstv // Gosudarstvo i biznes v sisteme pravovyx koordinat : monografiya / A. V. Gabov, V. N. Litovkin, O. V. Gutnikov [i dr.] ; otv. red. A. V. Gabov. - M. : IZiSP; Infra-M, 2014. - S. 112-120.

18. Molchanov A. A. Formirovanie pravovogo statusa krestyanskix (fermerskix) xozyajstv $v$ svete reformy grazhdanskogo zakonodatelstva // Vestnik Sankt-Peterburgskogo universiteta MVD Rossii. — 2013. — № 4 (60) . - S. 68-72.

19. Nauchno-prakticheskij kommentarij k Grazhdanskomu kodeksu Rossijskoj Federacii : v 2 t. / pod red. T. E. Abovoj, A. Yu. Kabalkina. - 7-e izd., pererab. i dop. - M. : Yurajt, 2012. - T. 1 : Chasti I, II GK RF. $923 \mathrm{~s}$.

20. Popova O. V. Priznaki krestyanskogo (fermerskogo) xozyajstva // Yurist. - 2018. — № 5. - S. 44-50.

21. Safin Z. F. Novoe v grazhdansko-pravovom polozhenii krestyanskix (fermerskix) xozyajstv // Uchenye zapiski Kazanskogo universiteta. Seriya : Gumanitarnye nauki. - 2013. - № 4. - S. 151-156.

22. Spektor E. I. Problemy v zakonodatelstve i puti ix preodoleniya : avtoref. dis. ... kand. yurid. nauk. - M., 2003. $-21 \mathrm{~s}$. 
23. Suxanov E. A. Predprinimatelskie korporacii v novoj redakcii Grazhdanskogo kodeksa Rossijskoj Federacii // Zhurnal rossijskogo prava. - 2015. - № 1. - S. 5-13.

24. Tagirova A. V. Pravovoj status krestyanskix (fermerskix) xozyajstv v usloviyax modernizacii grazhdanskogo zakonodatelstva // Vestnik Omskoj yuridicheskoj akademii. - 2018. - № 1. - S. 107-111.

25. Tyutereva N. N. Aktualnye problemy pravovogo polozheniya krestyanskogo (fermerskogo) xozyajstva // Pravo i ekonomika. - 2018. - № 12. - S. 53-59.

26. Ustyukova V. V. Grazhdansko-pravovoe regulirovanie sozdaniya i funkcionirovaniya krestyanskix (fermerskix) xozyajstv kak subektov predprinimatelskoj deyatelnosti // Predprinimatelskaya deyatelnost v selskom xozyajstve Rossii. Pravovye voprosy / otv. red. Z. S. Belyaeva, I. A. Ikoniczkaya. - M. : Institut gosudarstva i prava RAN, 1998. - S. 22-38.

27. Ustyukova V. V. Pravovoe polozhenie krestyanskogo (fermerskogo) i lichnogo podsobnogo xozyajstva v usloviyax agrarnoj reformy. - M. : Institut gosudarstva i prava RAN, 2000. - $192 \mathrm{~s}$.

28. Ustyukova V. V., Melnikov N. I. Razvitie pravovogo statusa krestyanskogo (fermerskogo) xozyajstva v zakonodatelstve Rossii // Agrarnoe i zemelnoe pravo. - 2013. - № 9 (105). - S. 18-26.

29. Xaritonova Yu. S. Pravosubektnost krestyanskogo (fermerskogo) xozyajstva v svete problem prava obshhej sobstvennosti ego chlenov // Zhurnal predprinimatelskogo i korporativnogo prava. - 2018. - № 2. S. $32-37$.

30. Yuridicheskie licza $v$ grazhdanskom prave : Yuridicheskie licza $v$ rossijskom grazhdanskom prave (kommercheskie i nekommercheskie organizacii) / otv. red. V. N. Litovkin, O. V. Gutnikov. - M. : IZiSP pri Pravitelstve RF, 2011. - 1024 s. 